\title{
ANALISIS PENGARUH DISIPLIN KERJA DAN BUDAYA ORGANISASI TERHADAP KINERJA KARYAWAN PT. PLN PERSERO AREA MUARA BUNGO
}

\author{
Amran, Tarmizi Taher \\ Program Studi Manajemen Fakultas Ekonomi \\ Universitas Muara Bungo
}

\begin{abstract}
ABSTRAK
Tujuan dari penelitian ini untuk mengetahui pengaruh yang signifikan antara disiplin kerja dan budaya organisasi terhadap kinerja karyawan pada PT. PLN Persero Area Muara Bungo secara parsial dan secara simultan. Jumlah populasi sebanyak 47 orang dan sampel adalah berjumlah 47 orang dengan metode penarikan sampel mengunakan Sampling Jenuh.

Berdasarkan hasil pengolahan data, diperoleh hasil persamaan regresi linier berganda sebagai berikut : $\mathrm{Y}=93,146+0,454 \mathrm{X}_{1}+13,106 \mathrm{X}_{2}+\mathrm{e}$ dari Uji-t menunjukkan bahwa variabel disiplin kerja dengan kinerja karyawan menunjukkan bahwa $t_{\text {hitung }} 2,734$ lebih besar dari $\mathrm{t}_{\text {tabel }}=2,015$ pada tingkat signifikasi 0,05 maka keputusannya adalah $\mathrm{H}_{0}$ ditolak $\mathrm{Ha}$ diterima, maka dapat di simpulkan bahwa disiplin kerja berpengaruh signifikan terhadap kinerja karyawan dan variabel budaya organisasi dengan kinerja karyawan menunjukkan bahwa $t_{\text {hitung }}=8,602$ lebih besar dari $t_{\text {tabel }}=2,015$ pada tingkat signifikasi 0,05 maka keputusannya adalah $\mathrm{H}_{0}$ ditolak $\mathrm{Ha}$ diterima, maka dapat di simpulkan bahwa budaya organisasi berpengaruh signifikan terhadap kinerja karyawan.

Berdasarkan uji secara simulatan secara bersama-sama (serentak) di peroleh nilai $F_{\text {hitung }}$ sebesar 162,608 dan $F_{\text {tabel }}$ sebesar 3,21, hal ini menyatakan variabel disiplin kerja dan budaya organisasi berpengaruh signifikan terhadap variabel kinerja karyawan. Berdasarkan hasil $\mathrm{R}^{2}=0,881$ hal ini berarti kontribusi $\mathrm{X}_{1}, \mathrm{X}_{2}$ terhadap $\mathrm{Y}$ adalah sebesar $88,1 \%$ dan sisanya sebesar $11,9 \%$ dapat dijelaskan oleh faktor-faktor lain diluar dari penelitian ini.
\end{abstract}

Kata Kunci : Disiplin kerja, Budaya organisasi dan Kinerja Karyawan

\section{PENDAHULUAN}

Setiap perusahaan akan berusaha untuk selalu meningkatkan kinerja karyawannya demi tercapainya tujuan yang telah ditetapkan perusahaan. Untuk mencapai tujuan kinerja memerlukan karyawan yang mempunyai kinerja kerja yang baik. Berbagai cara bisa ditempuh perusahaan dalam meningkatkan kinerja karyawannya diantaranya disiplin kerja, budaya organisasi, dan komunikasi sangat berperan dalam meningkatkan efektivitas dan efesiensi dari organisasi di dalam menjalankan kegiatan dan pekerjaan yang telah direncanakan dan diprogramkan.

Sumber daya manusia yang dimaksud adalah orang-orang yang memberikan tenaga, pikiran, bakat, kreativitas dan usahanya pada perusahaan. Setiap perusahaan berupaya untuk mendapatkan karyawan yang terlibat dalam kegiatan organisasi/perusahaan yang dapat memberikan kinerja karyawan. Pada kinerja karyawan yang tinggi untuk mencapai target yang telah ditetapkan perusahaan sebelumnya.

Salah satu faktor penentu keberhasilan perusahaan adalah kinerja dan kinerja karyawan. Pengukuran kinerja merupakan hal yang sangat penting dalam program manajemen secara keseluruhan. Pengukuran yang dilakukan secara berkelanjutan akan memberikan umpan balik yang merupakan hal yang sangat 
penting dalam upaya perbaikan kinerja secara terus menerus dalam mencapai keberhasilan dimasa yang akan datang.

Kinerja karyawan merupakan kinerja karyawan atau hasil kerja baik kualitas maupun kuantitas yang dicapai oleh seorang karyawan per satuan periode waktu dalam melaksanakan tugas kerjanya sesuai dengan tanggung jawab yang diberikan kepadanya. Setiap organisasi atau instansi dalam melaksanakan program yang diarahkan selalu berdaya guna untuk mencapai tujuan perusahaan. Salah satu caranya adalah meningkatkan kinerja karyawan.

Seorang karyawan dikatakan memiliki kinerja yang tinggi, jika beban kerja yang ditetapkan tercapai dan jika realisasi hasil kerja lebih tinggi dari pada yang ditetapkan perusahaan. Tuntutantuntutan yang tidak mampu dikendalikan oleh setiap karyawan ini akan menimbulkan ketegangan dalam diri karyawan dan jika tidak dapat diatasi maka karyawan tersebut akan mengalami penurunan semangat keja dan disiplin kerja. Untuk mencapai kinerja yang tinggi pimpinan perusahaan harus memperhatikan disiplin kerja.

Disiplin kerja adalah suatu sikap, perilaku yang dilakukan secara sukarela dan penuh kesadaran serta keadaan untuk mengikuti peraturan yang telah ditetapkan perusahaan baik tertulis maupun tidak tertulis (Nitisemito, 2002). Hilangnya disiplin akan berpengaruh terhadap efisiensi kerja dan efektivitas tugas pekerjaan. Bilamana disiplin kerja tidak dapat ditegakkan maka kemungkinan tujuan yang telah ditetapkan tidak dapat dicapai secara efektif dan efisien. Sebagai gambaran apabila suatu perusahaan hanya memperhatikan tentang pendidikan, keahlian dan teknologi tanpa memikirkan semangat dan disiplin kerja karyawan, maka pendidikan, keahlian dan teknologi yang tinggi sekalipun tidak akan menghasilkan produk yang maksimal bila yang bersangkutan tidak dapat memanfaatkannya secara teratur dan mempunyai kesungguhan disiplin kerja yang tinggi.

Disiplin merupakan bentuk pengendalian diri dari karyawan, pelaksanaan yang teratur akan dapat meningkatkan kesungguhan tim dalam bekerja pada sebuah organisasi serta tindakan disiplin menuntut standar-standar yang ditentukan. Oleh karena itu tindakan disiplin haruslah tidak diterapkan secara sembarangan, melainkan memerlukan pertimbangan yang bijaksana. Dengan terbentuknya atau terciptanya disiplin yang tinggi maka akan mendukung tercapainya tujuan perusahaan atau organisasi (Hariandja, 2002).

Disiplin kerja yang baik mencerminkan besarnya tanggung jawab seseorang terhadap tugas yang diberikan kepadanya. Hal itu dapat mendorong adanya gairah kerja,semangat kerja dan terwujudnya tujuan perusahaan oleh karena itu, seorang manajer harus bertindak tegas agar para bawahannya mempunyai disiplin yang baik. Seorang manajer dikatakan efektif dalam kepemimpinannya jika para bawahannya berdisiplin dengan baik (Hasibuan, 2003)

Dengan meningkatkan disiplin kerja, maka karyawan dapat mengerjakan tugasnya dengan baik, absensi dapat diperkecil seminimal mungkin, dan ini berarti meningkatkan kinerja karyawan. Pada dasarnya kerja yang bermalasmalasan atau tidak disiplin bukanlah akan membangun perekonomian akan tetapi akan menghambat kemajuan yang semestinya akan tercapai. Sebaliknya kerja yang efektif dan efisien menurut standar jam kerja yang telah ditetapkan serta beban kerja yang seasuai dengan kemampuan serta mendorong kelancaran berproduksi secara menyeluruh, selain disiplin kerja, budaya organisasi juga dapat meningkatkan kinerja karyawan.

Budaya organisasi adalah suatu sistem makna bersama yang dianut oleh anggota-anggota yang membedakan organisasi itu dari organisasi-organisasi lain (Robbin, 2002). Budaya organisasi 
merupakan suatu sitem nilai yang diperoleh dan dikembangkan oleh organisasi dan pola kebiasaan dan falsafah dasar pendirinya, yang terbentuk menjadi aturan yang digunakan sebagai pedoman dalam berfikir dan bertindak dalam mencapai tujuan organisasi.

Budaya organisasi merupakan hal yang sangat penting bagi suatu organisasi, karena akan selalu berhubungan dengan kehidupan yang ada dalam suatu organisasi tersebut serta cara kerja yang ditunjukan pegawai dalam suatu organisasi. Budaya memberikan identitas bagi para anggota organisasi dan membangkitkan komitmen terhadap keyakinan dan nilai yang lebih besar dari dirinya sendiri. Meskipun ide-ide ini telah menjadi bagian budaya itu sendiri yang bisa datang di manapun organisasi itu berada. Suatu organisasi budaya berfungsi untuk menghubungkan para anggotanya sehingga mereka tahu bagaimana berinteraksi satu sama lain dan selain dari itu budaya organisasi merupakan suatu sistem nilai yang diperoleh dan dikembangkan oleh organisasi dan pola kebiasaan dan falsafah dasar pendirinya, yang terbentuk menjadi aturan yang digunakan sebagai pedoman dalam berfikir dan bertindak dalam mencapai tujuan organisasi.

Budaya organisasi merupakan pemegang peran penting dalam pencapaian target perusahaan. Seperti bagaimana hubungan yang seharusnya terjadi di antara atasan terhadap bawahan, bawahan terhadap atasan dan juga hubungan dengan rekan kerja. Komunikasi yang efektif guna memperlancar komunikasi yang baik menyangkut komunikasi internal maupun komunikasi eksternal. Disiplin kerja, budaya organisasi di perusahaan merupakan faktor penting untuk menciptakan lingkungan yang nyaman demi meningkatkan kinerja karyawannya.

Adapun budaya organisasi di PT. PLN Persero Wilayah Sumatera Selatan Jambi Bengkulu (WS2JB) Area Muara Bungo bedasarkan indukator dalam penelitian ini dimana seluruh karyawan harus bisa mencurahkan kemampuan kerjanya secara maksimal, dapat bekerja sama dengan rekan kerja atau saling membantu dalam melaksanakan pekerjaan, dalam bekerja karyawan diberikan kenyamanan dalam bekerja dengan memberikan asuransi kesehatan kepada karyawan, dan untuk karyawan yang memilki kinerja yang baik akan diberikan penghargaan seperti kenaikan jabatan.

Perusahaan Listrik Negara (PLN) adalah sebuah BUMN yang mengurusi semua aspek kelistrikan yang ada di Indonesia. Perusahaan yang memiliki moto " listrik untuk kehidupan yang lebih baik " ini terus berupaya dalam peningkatan mutu kerja. PLN sebagai Badan Usaha Milik Negara yang ada di Indonesia sangat berpengaruh dalam perkembangan dunia usaha dan masyarakat dalam menjalankan usahanya, karena kebanyakan dari perusahaan milik pemerintah tersebut telah memonopoli beberapa bidang usaha yang mengatur kehidupan dan kebutuhan hidup masyarakat banyak. Oleh karna itu, dalam mengatur dan menjalankan usahanya, BUMN diatur dan dikelola oleh pemerintah karena sangat berhubungan dengan nasib masyarakat Indonesia. Badan-Badan Usaha Milik Negara tersebut, diharapkan dapat memenuhi kebutuhan dan keinginan dari dunia usaha pada umumnya dan masyarakat pada khususnya.

Sumber daya manusia diakui sebagai unsur yang sangat penting dan merupakan aset perusahaan, dimana manusia memiliki : sikap, cara berpikir, kebutuhan, keinginan bretanggung jawab dan adanya tingkat keterampilan yang berbeda-beda, maka diperlukan pengolahan yang baik, melihat besarnya peranan karyawan dalam pelaksanaan perusahaan maka sewajarnya bila perusahaan mencurahkan perhatiannya pada karyawan dengan membuat program keselamatan kerja karyawan yang baru dan berkualitas. 
PT. PLN Persero Wilayah Sumatera Selatan Jambi Bengkulu (WS2JB) Area Muara Bungo yang merupakan salah satu perusahaan yang berada dibawah naungan BUMN yang beralamat di jalan Sultan Thaha No. 771 Muara Bungo, Kabupaten Bungo Provinsi Jambi sudah menerapkan program keselamatan kerja. Menurut Angga Permana, staf SDM, PT. PLN Persero Wilayah Sumatera Selatan Jambi Bengkulu (WS2JB) Area Muara Bungo ini menerapkan program keselamatan kerja dengan pola K7 yaitu kedisiplinan, keindahan, kerapian, kenyamanan, kesantunan, kekeluargaan, dan kebersihan.

Berdasarkan hasil survei yang dilakukan pada perusahaan, masih terdapat beberapa karyawan yang tidak mengikuti peraturan, seperti adanya karyawan yang absen, sakit, izin dan tanpa keterangan. Data ini bisa dilihat pada tabel dibawah ini yang merupakan rekapitulasi absensi dari tahun 2019 sebagai berikut :

\section{Daftar Absensi Karyawan Pada PT. PLN Persero Area Muara Bungo Tahun 2019}

\begin{tabular}{|c|c|c|c|c|c|c|c|}
\hline Bulan & $\begin{array}{c}\text { Jumlah } \\
\text { Karyawan }\end{array}$ & $\begin{array}{c}\text { Hari } \\
\text { Kerja }\end{array}$ & I & $\mathbf{S}$ & CT & $\begin{array}{c}\text { Jumlah } \\
\text { Karyawan } \\
\text { Absen }\end{array}$ & $\%$ \\
\hline Januari & 47 & 26 & 2 & 4 & 0 & 6 & 0,49 \\
\hline Februari & 47 & 26 & 3 & 3 & 1 & 7 & 0,57 \\
\hline Maret & 47 & 26 & 1 & 3 & - & 4 & 0,33 \\
\hline April & 47 & 25 & 3 & 2 & 1 & 6 & 0,51 \\
\hline Mei & 47 & 26 & - & 3 & - & 3 & 0,25 \\
\hline Juni & 47 & 25 & 1 & - & 1 & 2 & 0,17 \\
\hline Juli & 47 & 25 & 2 & 2 & - & 4 & 0,34 \\
\hline Agustus & 47 & 26 & 1 & 3 & - & 4 & 0,33 \\
\hline September & 47 & 25 & 3 & 2 & - & 5 & 0,43 \\
\hline Oktober & 47 & 26 & - & 3 & - & 3 & 0,25 \\
\hline November & 47 & 26 & 1 & 2 & - & 3 & 0,25 \\
\hline Desember & 47 & 25 & - & 2 & - & 2 & 0,17 \\
\hline \multicolumn{5}{|c|}{ Jumlah } & & & 4,09 \\
\hline \multicolumn{5}{|c|}{ Rata-rata } & & & $\mathbf{0 , 3 4}$ \\
\hline
\end{tabular}

Sumber : PT. PLN Persero Area Muara Bungo, Tahun 2019

Berdasarkan Tabel 1.1 tingkat absensi mengalami kenaikan dan penurunan atau berfluktuasi setiap bulannya dengan persentase rata-rata $0,34 \%$ adapun tingkat persentase absensi dihitung berdasarkan rumus yaitu tingkat absensi dibagi jumlah hari kerja dibagi jumlah karyawan dikali seratus persen (100\%), tingkat absensi karyawan yang paling tertinggi terdapat pada bulan April yaitu sebesar $0,51 \%$ dan yang terendah pada bulan Juni dan Desember sebesar $0,17 \%$ dimana karyawan lebih banyak bekerja kerena menyelesaikan target pekerjaan, dari data diatas dapat dilihat tidak semua karyawan hadir, namun demikian sudah dapat dikatakan baik kerena tingkat absensi karyawan masih dibawah $1 \%$. Adapun indikator yang terkait kedalam disiplin kerja karyawan yang pertama adalah sikap perilaku karyawan, kesadaran atau kerelaan dirinya sendiri dalam melaksanakan tugas dan peraturan perusahaan yang terdiri dari kehadiran karyawan dalam bekerja, yang kedua norma adalah peraturan dimana keberadaan karyawan di tempat kerja untuk bekerja sesuai dengan jam kerja 
yang telah ditentukan yaitu masuk kerja jam 08.00 Wib dan pulang jam 16.00 Wib.

Dalam perusahaan ini karyawan di tuntut untuk mampu menyelesaikan tugas dan tanggung jawabnya secara efektif dan efisien. Keberhasilan karyawan dapat di ukur melalui tercapainya target pekerjaan secara optimal. Kinerja karyawan PT. PLN Persero Area Muara Bungo juga dapat diukur melalui penyelesaian tugasnya secara epektif dan efisien. Adapun tingkat kinerja karyawan PT. PLN Persero Area Muara Bungo salah satunya dapat diihat dari target penyaluran $\mathrm{KWh}$ dan penjualannya kepada masyarakat, Untuk lebih jelas dapat dilihat pada tabel berikut ini :

Targenyaluran KWh dan KWh yang terjual pada PT. PLN Persero Area Muara Bungo Januari - Nopember 2019

\begin{tabular}{|l|c|c|c|}
\hline & KWh tersalur (KWh) & $\begin{array}{c}\text { Kwh terjual } \\
(\text { KWh })\end{array}$ & Susut (\%) \\
\hline Januari & 8.009 .901 & 6.922 .992 & 16 \\
\hline Februari & 9.117 .640 & 7.661 .882 & 19 \\
\hline Maret & 8.752 .706 & 7.611 .049 & 15 \\
\hline April & 9.640 .014 & 8.311 .142 & 16 \\
\hline Mei & 9.868 .014 & 8.506 .909 & 16 \\
\hline Juni & 9.358 .111 & 8.067 .337 & 16 \\
\hline Juli & 10.452 .727 & 8.933 .955 & 17 \\
\hline Agustus & 9.177 .293 & 7.843 .840 & 17 \\
\hline September & 9.788 .998 & $8.295 . .761$ & 18 \\
\hline Oktober & 9.849 .861 & 8.418 .685 & 17 \\
\hline Nopember & 9.841 .200 & 8.340 .000 & 18 \\
\hline Desember & 9.580 .500 & 8.560 .000 & 12 \\
\hline
\end{tabular}

Sumber : PT. PLN Persero Area Muara Bungo (2019)

Dari tabel 1.2 dijelaskan tingkat kinerja karyawan dapat dikorelasikan dengan pencapaian target penyaluran KWh dan KWh yang terjual oleh PT. PLN Persero Area Muara Bungo dari bulan Januari sampai dengan Nopember 2020 terjadi fluktuatif penyaluran dan penjualan KWh pada tiap bulannya. Hal itu dikarenakan sering terjadi kerusakan pada mesin produksi dan gangguan cuaca. Dengan demikian adapun $\mathrm{KWh}$ yang belum terjual akan dikirim kembali ke kantor pusat.

Berdasarkan data diatas dapat dapat dilihat bahwa kinerja karyawan PT. PLN
Persero Area Muara Bungo dapat dikatakan belum maksimal dimana karyawan belum bisa menyelesaikan target penyaluran KWh dan penjualannya secara keseluruhan setiap bulannya. Namun bila dibandingkan dengan tingkat absensi karyawan $0,36 \%$ yang masih tergolong rendah dan budaya organisasi telah disusun berdasar ketentuan yang telah ditentukan, dengan demikan hal ini menimbulkan suatu fenomena yang menarik untuk diteliti. Berdasarkan uraian di atas, penulis tertarik untuk melakukan suatu penelitian dengan judul "Analisis Pengaruh Disiplin Kerja dan Budaya 


\section{Organisasi Terhadap Kinerja Karyawan Pada PT. PLN Persero Area Muara Bungo Kabupaten Bungo".}

\section{KAJIAN PUSTAKA \\ Manajemen Sumber Daya Manusia}

Menurut Gary Dessler (2006), manajemen sumber daya manusia adalah proses memperoleh, melatih, menilai, dan memberikan komfirmasi kepada karyawan, memperhatikan hubungan kerja mereka, kesehatan, keamanan dan masalah keadilan. Menurut Hasibuan (2003), mengemukakan bahwa manajemen sumber daya manusia manajemen sumber daya manusia adalah ilmu dan seni mengatur hubungan dan peranan tenaga kerja agar efektif dan efisien membantu mewujudkan tujuan perusahaan, pegawai, dan masyarakat. Selanjutnya, Manjemen sumber daya manusia adalah suatu perencanaan, pengorganisasian, pengarahan, dan pengawasan atas pengadaan, pengembangan, kompensasi, pemeliharaan dan pemutusan hubungan kerja dengan maksud untuk mencapai tujuan organisasi perusahaan (Husein Umar, 2003)

Jadi dapat diambil kesimpulan bahwa manajemen sumber daya manusia adalah suatu proses memperoleh, melatih, menilai dan memberikan kompensasi kepada karyawan, memperhatikan hubungan kerja mereka, kesehatan, keamanan, dan masalah keadilan serta perencanaan, pengorganisasian dan pengarahan, dan pengawasan atas pengadaan, pengembangan, kompensasi, pengintegrasian, pemeliharaan, dan pemutusan hubungan kerja dengan maksud untuk mencapai tujuan organisasi perusahaan secara terpadu.

\section{Disiplin Kerja}

Menurut Saydam (2006), Disiplin kerja adalah sebagai suatu sikap, tingkah laku, dan peraturan yang sesuai dengan peraturan perusahaan baik tertulis atau tidak tertulis dan menurut Fathoni (2006), Disiplin kerja adalah kesadaran dan kesediaan seseorang menaati semua peraturan perusahaan dan norma-norma sosial yang berlaku. Menurut Siagian (2004), disiplin merupakan tindakan manajemen untuk mendorong para anggota organisasi memenuhi tuntutan berbagai ketentuan tersebut.

Dari beberapa pendapat diatas dapat disimpulkan bahwa yang dimaksud dengan disiplin kerja adalah sikap kesetiaan dan ketaatan seseorang atau sekelompok orang terhadap peraturan-peraturan baik perbuatan pada suatu perusahaan untuk tujuan tertentu, disiplin kerja yang tinggi dalam suatu perusahaan akan meningkatkan kinerja karyawan.

\section{Budaya Organisasi}

$$
\text { Menurut Robbin (2002) }
$$

menyatakan bahwa budaya organisasi adalah nilai-nilai dominan yang didukung oleh organisasi, yang dapat menggambarkan tentang cara-cara melakukan suatu pekerjaan di tempat tertentu serta asumsi kepercayaan dasar yang terdapat di antara anggota organisasi.

Menurut Pabunda (2006), budaya organisasi merupakan suatu sistem nilai, kepercayaan, dan kebiasaan dalam suatu organisasi yang saling berinteraksi dengan struktur sistem formalnya untuk menghasilkan norma-norma perilaku organisasi. Sedangkan Menurut Soetjipto (2007), budaya organisasi pada dasarnya merupakan norma-norma dan nilai-nilai yang berlaku di dalam organisasi, contohnya: kesigapan dalam memberikan pelayanan kepada para pelanggan, sedangkan nilai mencerminkan keyakinan atau kepercayaan mereka akan akan halhal tertentu yang mampu mendatangkan kesuksesan, contohnya: perhatian yang besar pada kepuasan para pelanggan.

Berdasarkan pengertian-pengertian di atas maka dapat disimpulkan bahwa budaya organisasi adalah nilai-nilai dominan yang didukung oleh organisasi, yang dapat menggambarkan tentang caracara melakukan suatu pekerjaan dan kebiasaan dalam suatu organisasi yang saling berinteraksi dengan struktur sistem 
formalnya untuk menghasilkan normanorma perilaku organisasi yang mencerminkan keyakinan atau kepercayaan mereka akan akan hal-hal tertentu yang mampu mendatangkan kesuksesan.

\section{Kinerja Karyawan}

Menurut Malthis dan Jackson, (2002) kinerja karyawan adalah hasil kerja seorang karyawan selama periode tertentu yang dinilai dengan serangkaian tolak ukur yang berkaitan langsung dengan tugas seseorang serta kriteria yang ditetapkan. Kinerja pada dasarnya adalah apa yang dilakukan atau tidak dilakukan karyawan. Kinerja karyawan adalah yang mempengaruhi seberapa banyak mereka memberi kontribusi kepada organisasi. Perbaikan kinerja baik untuk individu maupun kelompok menjadi pusat perhatian dalam upaya meningkatkan kinerja organisasi Istilah kinerja berasal dari kata job performance atau actual performance yang berarti kinerja karyawan atau prestasi sesunggunya yang dicapai seseorang. Menurut Mangkunegara (2000) "kinerja adalah hasil kerja yang dihasilkan oleh seorang karyawan untuk mencapai tujuan yang diharapkan”. Sopiah, (2008) menyatakan lingkungan juga bisa mempengaruhi kinerja seseorang. Situasi lingkungan yang kondusif, misalnya dukungan dari atasan, teman kerja, sarana dan prasarana yang memadai akan menciptaka kenyamanan tersendiri dan akan memacu kinerja yang baik.

Dari beberapa pendapat diatas dapat disimpulkan bahwa yang dimaksud kinerja adalah hasil kerja yang dicapai setiap karyawan sehingga dapat memberikan kontribusi terhadap perusahaan. Penilaian kinerja merupakan proses yang dilakukan perusahaan dalam mengevaluasi kinerja pekerjaan perusahaan.

\section{METODOLOGI PENELITIAN}

Jenis penelitian ini adalah penelitian deskriptif kuantitatif yang dapat digunakan untuk meneliti pada populasi atau sampel tertentu, pengumpulan data mengunakan instrument penelitian, analisis data bersifat kuantitatif/statistik, dengan tujuan untuk menguji hipotesis yang telah ditetapkan (Sugiyono, 2012). Adapun teknik penarikan sampel mengunakan metode Sampling Jenuh dimana anggota populasi digunakan sebagai sampel karena jumlah populasi relatif kecil (Sugiyono, 2012). Adapun jumlah sampel dalam penelitian ini sebanyak 47 orang.

\section{HASIL PENELITIAN DAN \\ PEMBAHASAN}

\section{Hasil Uji t (Parsial)}

Uji-t bertujuan untuk mengetahui besarnya pengaruh masing-masing variabel independen secara individual (parsial) terhadap variabel dependen. Nilai $\mathrm{t}$ hitung diperoleh dengan menggunakan Program Software SPSS versi 25.00 for Windows, kemudian akan dibandingkan dengan nilai $t_{\text {tabel }}$ pada tingkat $\alpha=5 \%$ yakni diperoleh dengan derajat bebas ( $\mathrm{n}$ adalah jumlah sampel, $\mathrm{k}$ adalah jumlah variabel $\mathrm{x}$ dan y). Menurut (Sugiyono, 2012) df $=\mathrm{n}$ $\mathrm{k} \quad(\mathrm{n}=47, \mathrm{k}=3)$, jadi $47-3=44$ dan tingkat signifikasi sebesar alpha $5 \%(0,05$ $: 2$ tailed $)=0,025$ maka dapat diperoleh untuk $\mathrm{t}_{\text {tabel }}$ sebesar adalah 2,015. 
Coefficients $^{\mathrm{a}}$

\begin{tabular}{|c|c|c|c|c|c|c|c|c|}
\hline \multirow{2}{*}{\multicolumn{2}{|c|}{ Model }} & \multicolumn{2}{|c|}{$\begin{array}{l}\text { Unstandardized } \\
\text { Coefficients }\end{array}$} & \multirow{2}{*}{$\begin{array}{c}\begin{array}{c}\text { Standardize } \\
\mathrm{d}\end{array} \\
\text { Coefficients } \\
\text { Beta }\end{array}$} & \multirow{3}{*}{$\begin{array}{c}t \\
7,661\end{array}$} & \multirow{3}{*}{$\begin{array}{l}\text { Sig. } \\
0,000\end{array}$} & \multicolumn{2}{|c|}{$\begin{array}{c}\text { Collinearity } \\
\text { Statistics }\end{array}$} \\
\hline & & B & Error & & & & Tolerance & VIF \\
\hline \multirow[t]{3}{*}{1} & (Constant) & 93,146 & 12,159 & & & & & \\
\hline & $\begin{array}{l}\text { Disiplin } \\
\text { Kerja }\end{array}$ & 0,454 & 0,166 & 0,421 & 2,734 & 0,009 & 0,114 & 8,755 \\
\hline & $\begin{array}{l}\text { Budaya } \\
\text { Organisasi }\end{array}$ & 13,106 & 1,524 & 1,324 & 8,602 & 0,000 & 0,114 & 8,755 \\
\hline
\end{tabular}

a. Dependent Variable: Kinerja Karyawan

Berdasarkan hasil uji t (secara parsial) model regresi linier berganda dari penelitian ini sebagai berikut :

1. Uji parsial disiplin kerja $\left(\mathrm{X}_{1}\right)$ dengan kinerja karyawan (Y)

Uji parsial disiplin kerja dengan kinerja karyawan diperoleh nilai $t_{\text {hitung }}=2,734$ dan $t_{\text {tabel }}=2,015$ pada tingkat signifikasi 0,05 maka keputusannya adalah $\mathrm{H}_{0}$ ditolak $\mathrm{Ha}$ diterima, maka dapat di simpulkan bahwa disiplin kerja berpengaruh signifikan terhadap kinerja karyawan.
2. Uji parsial budaya organisasi $\left(\mathrm{X}_{2}\right)$ dengan kinerja karyawan (Y)

Uji parsial budaya organisasi dengan kinerja karyawan diperoleh nilai $t_{\text {hitung }}$ $=8,602$ dan $t_{\text {tabel }}=2,015$ pada tingkat signifikasi 0,05 maka keputusannya adalah $\mathrm{H}_{0}$ ditolak $\mathrm{Ha}$ diterima, maka dapat di simpulkan bahwa budaya organisasi $\left(\mathrm{X}_{2}\right)$ berpengaruh signifikan terhadap kinerja karyawan.

\section{Hasil Uji F (Simultan)}

Hasil uji F (secara serentak ) model regresi linier berganda dari penelitian ini sebagai berikut :

ANOVA $^{\mathrm{a}}$

\begin{tabular}{|l|l|r|r|r|r|l|}
\hline \multicolumn{2}{|l|}{ Model } & $\begin{array}{c}\text { Sum of } \\
\text { Squares }\end{array}$ & Df & $\begin{array}{c}\text { Mean } \\
\text { Square }\end{array}$ & F & Sig. \\
\hline 1 & Regression & 217,217 & 2 & 108,608 & 162,89 &, $000^{\mathrm{b}}$ \\
& & & & 5 & \\
\cline { 2 - 7 } & Residual & 29,336 & 44 & 0,667 & & \\
\cline { 2 - 7 } & Total & 246,553 & 46 & & & \\
\hline
\end{tabular}

a. Dependent Variable: Kinerja Karyawan 


\section{b. Predictors: (Constant), Budaya Organisasi, Disiplin Kerja}

Tabel di atas memperlihatkan nilai $\mathrm{F}$ hitung adalah 162,895 dengan tingkat signifikan 0,05. Menurut (Duwi Priyatno, 2009) Df $=\mathrm{n}-\mathrm{k}-1$ atau 47-2-1 $=44$ ( $\mathrm{n}$ adalah jumlah responden dan $\mathrm{k}$ adalah jumlah variabel independen), hasil diperoleh untuk $F_{\text {tabel }}$ sebesar 3,21. Dimana nilai $F_{\text {hitung }} 162,608>F_{\text {tabel }} 3,21$. Dengan demikian hipotesis $\mathrm{H}_{0}$ ditolak dan $\mathrm{H}_{\mathrm{a}}$ diterima. Artinya, secara bersama-sama (serentak) variabel-variabel independent yaitu disiplin kerja $\left(\mathrm{X}_{1}\right)$ dan budaya organisasi $\left(\mathrm{X}_{2}\right)$ yang dipersepsikan berpengaruh signifikan terhadap variabel dependent (Y) yaitu kinerja karyawan.

\section{Model Summary ${ }^{b}$}

\begin{tabular}{|l|r|r|r|r|r|}
\hline Model & R & R Square & $\begin{array}{r}\text { Adjusted } \\
\text { R Square }\end{array}$ & $\begin{array}{r}\text { Std. Error of } \\
\text { the Estimate }\end{array}$ & $\begin{array}{c}\text { Durbin- } \\
\text { Watson }\end{array}$ \\
\hline 1 &, $939^{\mathrm{a}}$ & 0,881 & 0,876 & 0,81654 & 1,969 \\
\hline
\end{tabular}

a. Predictors: (Constant), Budaya Organisasi, Disiplin Kerja

b. Dependent Variable: Kinerja Karyawan

Berdasarkan hasil uji determinasi $\left(\mathrm{R}^{2}\right)=0,881$ dapat disimpulkan bahwa variabel disiplin kerja $\left(\mathrm{X}_{1}\right)$ dan budaya organisasi $\left(\mathrm{X}_{2}\right)$ memiliki kemampuan dalam menerangkan variasi variabel kinerja karyawan (Y) sebesar 88,1\% dan sisanya sebesar $11,9 \%$ dapat dijelaskan oleh faktor-faktor lain diluar dari penelitian ini. Hal ini menunjukkan bahwa disiplin kerja serta budaya organisasi dapat memberikan berpengaruh terhadap kinerja karyawan sehingga karyawan akan berusaha untuk meningkatkan kinerjanya.

\section{PENUTUP}

Berdasarkan hasil analisis dan pembahasan yang telah diuraikan sebelumnya maka akan disajikan beberapa kesimpulan yaitu sebagai berikut :

1. Secara parsial ditunjukkan bahwa kesimpulan yang diambil dari setiap variabel independent yaitu disiplin kerja $\left(\mathrm{X}_{1}\right)$ dan budaya organisasi $\left(\mathrm{X}_{2}\right)$ yang dipersepsikan yaitu:

a. Uji parsial disiplin kerja dengan kinerja karyawan diperoleh nilai $t_{\text {hitung }}=2,734$ lebih besar dari $t_{\text {tabel }}=$
2,015 pada tingkat signifikasi 0,05 maka keputusannya adalah $\mathrm{H}_{0}$ ditolak Ha diterima, maka dapat di simpulkan bahwa disiplin kerja berpengaruh signifikan terhadap kinerja karyawan

b. Uji parsial budaya organisasi dengan kinerja karyawan diperoleh nilai $t_{\text {hitung }}=8,602$ lebih besar dari $\mathrm{t}_{\text {tabel }}=2,015$ pada tingkat signifikasi 0,05 maka keputusannya adalah $\mathrm{H}_{0}$ ditolak $\mathrm{Ha}$ diterima, maka dapat di simpulkan bahwa budaya organisasi $\left(\mathrm{X}_{2}\right)$ berpengaruh signifikan terhadap kinerja karyawan.

2. Secara simultan ditunjukkan bahwa nilai $F_{\text {hitung }} 162,608$ lebih besar dari $F_{\text {tabel 3,21. Dengan demikian }}$ hipotesis $\mathrm{H}_{\mathrm{o}}$ ditolak dan $\mathrm{H}_{\mathrm{a}}$ diterima. Artinya, secara bersamasama (serentak) variabe disiplin kerja dan budaya organisasi berpengaruh signifikan terhadap variabel kinerja karyawan. 
3. Dari hasil pengujian koefisien determinasi maka diperoleh Rsquare sebesar 0,881 angka ini menyatakan bahwa variabel disiplin kerja $\left(\mathrm{X}_{1}\right)$ dan budaya organisasi $\left(\mathrm{X}_{2}\right) \quad$ memiliki kemampuan dalam menerangkan variasi variabel kinerja karyawan sebesar $88,1 \%$ dan sisanya sebesar $11,9 \%$ dapat dijelaskan oleh faktor-faktor lain diluar dari penelitian ini.

Saran

Berdasarkan hasil pembahasan dan analisis sebelumnya maka dapat dikemukan saran-saran sebagai berikut :

1. Variabel disiplin kerja indikator yang terendah adalah tangung jawab, hendaknya karyawan harus lebih bertanggung jawab dalam menyelesaikan pekerjaan sehingga pekerjaan dapat terselesaikan secara maksimal.

2. Variabel budaya organisasi dengan indikator yang terendah adalah rasa aman, hendaknya pimpinan harus lebih memperhatikan kenyaman karyawan dalam bekerja terutama karyawan di bagian lapangan dengan pekerjaan yang memiliki resiko yang tinggi.

3. Variabel kinerja karyawan indikator yang paling terendah adalah kuantitas, yang mana hendaknya karyawan dapat lebih meningkatkan kemampuan kerja agar pekerjaan dapat terselesaikan dengan baik.

4. Penelitian ini menggunakan tiga variabel untuk mengukur disiplin kerja dan budaya organisasi terhadap kinerja karyawan dan bagi peneliti selanjutnya diharapkan mengambil variabel bebas lainnya untuk mengukur variabel kinerja karyawan.

\section{DAFTAR PUSTAKA}

Arikunto, Suharsimi, 2006. Prosedur Penelitian Suatu Pendekatan Praktek, Rhineka Cipta, Jakarta

Dessler, Gary, 2006. Manajemen Sumber Daya Manusia. Index, Jakarta

Fakultas Ekonomi Universitas Muara Bungo, 2012. Buku Pedoman Bimbingan dan Skripsi, Muara Bungo.

Fathoni, Abdurrahmat, 2006. Organisasi dan Manajemen Sumber daya Manusia, cetakan pertama, Rineka Cipta Jakarta.

Fauziawati, Asti, 2013. Pengaruh Disiplin kerjaTerhadap Kinerja Karyawan (Survey pada karyawan direktorat surat dan paket PT. Pos Indonesia Persero Bandung, Skripsi Univesitas Pendidikan Indonesia

Hariandja, Marihot Tua Efendi, 2002. Manajemen Sumber Daya Manusia, PT Grasindo, Jakarta.

Hasibuan, Malayu S.P, 2003, Manajemen Sumber Daya Manusia, Edisi Revisi. Bumi Aksara, Jakarta.

Handoko, T, Hani, 2001, Manajemen, Cetakan Kedelapan belas, BPFE Yogyakarta.

Mathis, Robert L dan Jhon H Jakson, 2002. Manajemen Sumber daya Manusia, PT. Salemba Empat, Jakarta

Mangkunegara, 2000, Manajemen Sumber Daya Manusia Perusahaan, Cetakan Kelima, Remaja Rosdakarya, Bandung

Miftahul, Rifki, 2013. Pengaruh Kepuasan Kerja dan Disiplin Kerja Terhadap Kinerja Karyawan pada PT Tri Keeson Utama Garut, 
Jurnal Universitas Komputer Indonesia

Pabundu, 2010. Budaya Organisasi dan Peningkatan Kinerja Karyawan.: Bumi Aksara, Jakarta

Priyatno, Duwi, 2009. SPSS Untuk Analisis Korelasi, Regresi, dan Multivariate, Penerbit Gava Media, Yogyakarta.

Puspika, Iis, 2012. Pengaruh Disiplin Kerja terhadap kinerja karyawan Pegawai pada Rutan Klas 1 di Bandar Lampung, Jurnal Organisasi dan Manajemen

Porwani, Sri, 2010. Pengaruh Budaya Organisasi terhadap Kinerja Karyawan Studi Kasus: PT. Tambang Batubara Bukit Asam (Persero) Tanjung Enim. Jurnal Ilmiah,

Robbins, Stephen P., 2002. Organizational Behavior, Prentice Hall Inc., New Jersey.

Soetjipto, Budi W, 2007. Budaya Organisasi dan Perubahan, Penerbit PT. Elex Media Komputindo, Jakarta.

Siswanto, 2002. Manajemen Tenaga Kerja Indonesia, PT Bumi aksara. Jakarta.
Saydam, Gauzali, 2006. Manajemen Sumber Daya manusia Suatu Pendekatan Mikro, Penerbit Djambatan. Jakarta.

Sarwanto, Joko, 2007. Pengaruh disiplin kerja terhadap kinerja karyawan di Kantor Depatemen Agama Kabupaten Karanganyar, Skripsi Universitas Islam Negeri Sunan Kali jaga Yogyakarta

Siagian, Sondang, 2004. Manajemen Sumber Daya Manusia, Edisi 1, Cetakan II, Penerbit PT. Bumi Aksara, Jakarta

Sopiah, 2008. Perilaku Organisasional. Yogyakarta: Andi Offset.

Sinungan, 2003. Manajemen Sumber Daya Manusia, Bumi Aksara, Jakarta

Sugiyono, 2012. Statisatika Untuk Penelitian, Alfabeta, Bandung

Sutrisno Edi, 2009. "Manajemen Sumber Daya Manusia", Kencana Prenada Media Group, Jakarta

Umar, Husein, 2004. Metode Penelitian untuk Skripsi dan Tesis Bisnis. Jakarta.

Zainal, Fudin, 2013. Pengaruh Disiplin kerja Kerja terhadap Kinerja karyawan pada PT. Rekatama Putra Gegana Bandung, Skripsi Universitas Winaya Mukti Bandung 